\title{
Mærkværdiggørelsen af dansk litteratur: \\ for en ny fordeling af litteraturhistorisk dumhed og blindhed
}

Af Dag Heede

Den litterare kanon kan og bor nyleses og litteraturbistorien omskrives $i$ lyset af queer teori. En ny markelig dansk litteraturbistorie er et projekt, der soger at lirke en rakke klassikere ud af heteronormativitetens ideologiske jerngreb. ${ }^{1}$
I

foråret 2002 udkom den danske oversættelse af Jackie Wullschlagers omfattende engelske H.C. Andersenbiografi, Hans Christian Andersen. The life of a storyteller (2000); et solidt, omfattende, grundigt værk i den angelsaksiske lifeand-work-tradition præget af hæderlighed og commonsense. Wullschlager inddrager som den naturligste ting i verden også H.C. Andersens mange dybe og mestendels ulykkelige forelskelser i en række unge mænd i sin udramatiske og snusfornuftige behandling. Hun er sandsynligvis blevet overrasket, da hendes bog blev betragtet som en sensation i det ellers i sin egen selvforståelse, så seksualliberale Danmark, der gik i homofobt selvsving over antydningen af H.C. Andersens mulige seksuelle afvigelse.

I selve DRls TV-Avis bliver hun i primetime (fejl)citeret for at påstå, at vores hellige og urørlige nationalskjald var "homoseksuel". Og i et anfald af journalistisk pxdofili fokuserede et længere indslag på en oplæsning af et Andersen-eventyr i en bør- 
nehave, hvis højdepunkt kom, da et af børnene blev udfrittet om, hvad det betød for hende, at digteren var "bøsse". I en vidunderlig og H.C. Andersen'sk afslutning med ekkoer til "Kejserens nye Klæder" svarer den lille pige afvæbnende, at det vidste hun ikke, men at hun syntes, at eventyrene var dejlige. Måske var interviewet hendes første møde med et centralt kulturelt problem: mænds positive følelser for andre mænd.

\section{HOMOSOCIALT BEGÆR}

I sin epokegørende bog The Epistemology of the Closet (1990) lægger den amerikanske litterat Eve Kosofsky Sedgwick ud med brask og bram. Hun erklærer enhver analyse af hvilket som helst fænomen i det tyvende århundrede for ikke blot mangelfuld, men i sin kerne forfejlet, i den grad den ikke medtænker forvaltningen af begær imellem især mænd. Hun påstår, at problemet med hvad vores kultur skal stille op med følelser, begær og venskab mænd og mænd imellem (og i mindre grad kvinder og kvinder imellem) på grundlæggende vis har påvirket det tyvende århundrede. Spørgsmålet om forvaltningen af mænds forhold til mænd rækker langt ud over det rent seksuelle. Med sit hjemmelavede begreb om "homosocialt begær" ("homosocial desire") søger Sedgwick at indfange et meget bredt spektrum af sammekønnede relationer fra genitalseksualitet over kammerateri, kollegialitet, positiv særbehandling og en lang række monoseksuelle mandesammenhænge.

Som et særkende for den moderne vestlige verden har vi i det seneste halvandet hundrede år søgt at løse spørgsmålet med "homosocialt begxr" ved at konstruere to særkategorier, "homoseksualitet" og "heteroseksualitet”. Men vi har lige så længe været plaget af grænsedragningsspørgsmål, da ingen præcis ved, hvor og hvordan grænserne mellem seksualitet og socialitet går. Vores kultur er således hjemsøgt af en usalig trang til igen og igen at iscenesætte og rekonstruere disse grænsedragninger.
Dette sker ofte på uhyre dramatisk vis. Spørgsmålet og de derved forbundne smertepunkter har redet - og vedbliver at ride vores kultur (især den mandlige del af den) som en mare.

Homoseksualitets/heteroseksualitets-binariteten har indflydelse langt ud over seksualiteten. Den er ifølge Sedgwick en grundlæggende struktur i den vestlige modernitet på linje med køn, klasse og race. Forvaltningen af homosocialt begær udgør en nu kronisk defineringskrise, som påvirker en lang række centrale modsætninger i vores kultur: hemmeligholdelse/afsløring, viden/uvidenhed, naturlighed/kunstighed, ny/gammel, disciplin/terrorisme, kanonisk/ikke-kanonisk, helhed/dekadence, by/ land, hjemlig/udenlandsk, sundhed/ sygdom, enshed/forskel, aktiv/passiv, inde/ude, erkendelse/paranoia, kunst/ kitsch, utopi/ apokalypse, oprigtighed/ sentimentalitet og frivillighed/forfaldenhed. Ingen af disse fænomener kan forstås uden at medtænke de kulturelle grænsedragningsbestræbelser mellem heteroseksualitet/homoseksualitet.

For især såkaldt heteroseksuelle mænd vedbliver homoseksualiteten at være et problem, for ingen kan med sikkerhed definere, hvad der er homoseksuelt (eller - i forlængelse heraf - hvad der er "rent" heteroseksuelt). Vores kultur lider derfor af en grundlæggende homofobi, en fiksering på konstant og ofte melodramatisk at påkalde og besværge homoseksualitet. Vi befinder os således i en nu kronisk krisetilstand i omgangen med homosocialt begær, og vi er alle "gidsler" i homoseksualitets/heteroseksualitets-binariteten, hvad enten vi befinder os på den ene eller den anden side af opdelingen.

Denne "gidseltagning" præger hele den moderne kultur, herunder den moderne litteratur, der sat på spidsen kan anskues som - også - en lang række problematiseringer, påkaldelser, besværgelser og defineringsforsøg i forhold til homosocialt begxr. Men ikke bare litteraturen, også litteraturhistori- 
en kan - og må - betragtes som en arena for problematisering af begær mellem mænd og i mindre grad mellem kvinder.

\section{LITTERATURHISTORIEN SOM}

\section{HETERONORMATIV DISCIPLIN}

Historien er de sejrendes historie, lød en marxistisk parole fra min ungdom. Men historieskrivning - i hvert fald litteraturhistorieskrivning - er også en distribuering af lys og mørke, en autoritær bestemmelse af, hvad der kan, skal og må ses, og hvad der ikke må undersøges. Litteraturformidling, tekstanalyse og fortolkning er også en tilkendegivelse af, hvilke aspekter af en tekst, et forfatterskab, en biografi, en periode, der må undersøges, hvilke spørgsmål, der er legitime og relevante, og hvad der er upassende, irrelevant, latterligt, trivielt eller usagligt at spørge til. Litteraturhistorien er således også et katalog over, hvilke iagttagelser er tilladte, en fordeling af indsigter og blindheder, et manual til at bestemme, hvor og hvornår læseren skal se, og hvor hun skal lukke øjnene. Litteraturvidenskab er som andre vidensformer $i$ alle ordets betydninger en disciplin.

I forbindelse med skrivningen af en ny type litteraturhistorie, en queer, skæv eller mærkelig litteraturhistorie, der stiller nye typer spørgsmål, ser tekster i ny belysning og fra skæve, decentrerede vinkler, er det vigtigt ikke kun at have litteraturen som genstand, men også sekundærlitteraturen og litteraturhistorierne. Hvis en tekst rummer en problematisering af homosocialt begær (og det vil de fleste moderne tekster på mere eller mindre udfoldet og spændende vis gøre), må en queer litteraturtilgang ikke blot fokusere på denne, men også på de måder, hvorpå sekundærlitteraturen og litteraturhistoriske behandlinger har ignoreret, besvoret, fornægtet, "verneinet", fortiet, forvrænget, trivialiseret, romantiseret, banaliseret, sentimentaliseret, bortforklaret, censureret, dysforiseret, patologiseret, skandaliseret eller eksotiseret dette tema eller måske rettere: disse "forhandlinger" af den generelle, nu kroniske homo/heteroseksualitetsdefinitionskrise. Litteraturhistorien er således også et studie i homofobi, ikke forstået som en monolitisk undertrykkelseshistorie, men en lang række komplekse og varierede problematiseringer af et kulturelt smertepunkt.

En anden af Eve Kosofsky Sedgwicks betragtninger er her øjenåbnende: sammenhængen mellem magt og uvidenhed. At ånd er magt, er vi vant til at tænke, og med ikke mindst den franske filosof Michel Foucaults studier i galskab, kriminalitet, disciplin, sygdom og seksualitet har vi lært, at viden aldrig finder sted $i$ et historisk tomrum, og at kundskabs- og magtrelationer er tæe og intenst forbundne. Men Sedgwick har en vigtig pointe, når hun understreger også koblingerne mellem uvidenhed ("ignorance") og magt. Især i forbindelse med forvaltningen af homosocialt begær synes den naive, "rene", blinde position at borge for saglighed og objektivitet, mens det ofte kan være diskvalificerende at vide og at se for meget.

Denne blindhed eller rettere disse blindheder er ingenlunde hverken uskyldige eller oprindelige, men i høj grad konstruktioner, hvis historie og økonomi råber på analyse:

"If ignorance is not - as it evidently is not - a single Manichean, aboriginal maw of darkness from which the heroics of human cognition can occasionally wrestle facts, insights, freedoms, progress, perhaps there exists instead a plethora of ignorances, and we may begin to ask questions about the labor, erotics, and economics of the human production and distribution. Insofar as ignorance is ignorance of a knowledge - a knowledge that may itself, it goes without saying, be seen as either true or false under some other regime of truth these ignorances, far from being pieces of the originary dark, are produced by and correspond to particular knowledges and circulate as part of particular regimes of truth" (Sedgwick 1990,8). 
Den nye mærkelige danske litteraturhistorie er endnu ikke skrevet. Måske bliver den det heller aldrig. Men lad mig i det følgende blot præsentere et par skitseagtige nedslag, som måske kan fungere som idékatalog over kommende presserende projekter. Jeg indskrænker mig til kendte navne fra den etablerede kanon. Hermed hævder jeg ikke, at den danske litterære kanon ikke i sig selv bør udfordres og omdefineres ud fra en queer vinkel; men af overskuelighedsgrunde holder jeg mig til værker og forfattere, som må formodes kendte.

\section{H.C. ANDERSEN}

Lad os vende tilbage til indledningens næsten eventyrlige fortælling om Den lille Pige og Homoseksualiteten. Hvad siger denne episode om Danmark Anno 2002? Ja, blandt andet, at spørgsmålet om homoseksualitet stadig er et intenst smertepunkt, og at man tilsyneladende ikke kan indprente børn tidligt nok, at seksuel identitet, herunder den binære inddeling i homo- og heteroseksuel, er uhyre vigtig, og at den har en enorm indflydelse på alting. Tilsyneladende ligger vi stadig under for det Michel Foucault i sin seksualitetshistorie La volonté de savoir fra 1976 hånligt kaldte den vestlige kulturs "sexmonarki", vores frivillige underkastelse under en "Kong Sex", en illusorisk og historisk enestående kulturel illusion om "seksualiteten" som hemmeligt, kostbart, skrøbeligt og enormt betydningsbærende grundprincip, der styrer alle vores handlinger, tanker, drømme og forestillinger. Den bagvedliggende præmis i tv-indslaget var naturligvis, at "Den grimme $x l-$ ling" og "Fyrtøjet" aldrig bliver de samme igen, når det nu er "bevist", at H.C. Andersen "var bøsse".

Indslaget var en alvorlig og problematisk udspredning af dumhed og uvidenhed, en misinformation af dimensioner. Selvfølgelig var H.C. Andersen (1805-1875) ikke "homoseksuel" (eller endnu mere anakronistisk: "bøsse"), lige så lidt som han var kom- munist, cyklist, mobiltelefonbruger eller internetsurfer, og det påstår Wullschlager da heller ikke i sin bog. Som den danske bøssehistoriker Wilhelm von Rosen overbevisende har dokumenteret i afhandlingen Månens kulør (1993), forelskede H.C. Andersen sig intenst i mænd - og i kvinder, men disse forelskelser kan ikke fortolkes i moderne kategorier som "homoseksualitet" og "heteroseksualitet" eller evt. "biseksualitet”, bl.a. fordi disse først opstod i anden halvdel af det nittende århundrede. H.C. Andersen er derimod en uhyre spændende og mærkelig grænsefigur, hvis overdrevne dyrkelse af "det romantiske mandevenskab", en nu desværre forsvunden kategori, måske befandt sig på grænsen af det smagfulde og i samtiden acceptable. Denne grænseposition skal undersøges med historisk fingerspidsfornemmelse og genstandssensitivitet, og kræver langt mere fintmærkende begrebsapparater end ahistoriske homoseksualitetskategoriseringer og den senere sexologis binære enten/eller-opdelinger.

En queer litteraturhistoricering af H.C. Andersen må derfor først luge ud i litteraturhistoriens heteronormative og homofobe vrøvl og senere heteroseksualiserende myter. Herefter må den kortlægge den nu over hundrede år lange homoseksuelle mod-mytologisering, der startede med den danske forfatter Carl Fahlberg, der i 1901 under pseudonymet Albert Hansen skrev essayet "H.C. Andersen. Beweis seiner Homosexualität". Så må den i gang med at undersøge romanerne, dagbøgerne, brevene og eventyrene. Ikke nødvendigvis ud fra snævre biografiske kortslutninger eller med alt for faste begreber om litterære camouflager af "det homoerotiske", sådan som Heinrich Detering gør det i sin behandling af Andersen i sin afhandling, Das offene Geheimnis. Zur literarischen Produktivität eines Tabus von Winckelmann bis zu Thomas Mann (1994).

Selvfølgelig er det betydningsfuldt, at f.eks. "Den lille Havfrue" blev skrevet i 
1836, netop da den elskede Edvard Collin havde giftet sig. Men havfruen bør nok ikke kun læses håndfast og ahistorisk som en allegori på en homoseksuel mand i moderne forstand. Måske er det lige så frugtbart at se skikkelsen, der som bekendt er kommet til at symbolisere Danmark på turistkortet, som en transseksuel fantasi, en drømmende afprøvning af, om det er en god ide at skære "den" af og i kønsomvendt form forsøge at kapre drømmeprinsen. Det lykkedes som bekendt ikke, men Andersens berømte "lappeløsning" for havfruen, i form af en "luftånd", kan måske ses som en drøm om en anderledes identitet løsrevet fra kroppens jordiske krav. Nå, dette må vi høre mere om i 2005, hvor 200året for Andersens fødsel bliver fejret med brask og bram og i bevidst opposition til 150-års-jubilæets sentimentale Danny Kayeiscenesættelser i 1952, en fejring, der i høj grad også forhandlede med blindheder, viden og ikke-viden omkring homoseksualiteten (ikke mindst skuespillerens og hele musicalgenrens).

Konkluderende må opgaven for en mærkeliggørelse af H.C. Andersen være på den ene side en fastholdelse af begær og forelskelser i mænd, og på den anden at undgå anakronistiske kategoriseringer ud fra den senere homoseksualitets/heteroseksualitetsbinaritet. Historisk sensitive studier i H.C. Andersens liv og værk behøver jo ikke bekræfte vores narcissistiske forestillinger om, at verden og menneskeheden fra tidernes morgen har været inddelt i hetero- og homoseksuelle. De kan tværtimod belære os om, at menneskets begær er langt mere mangfoldigt end de stivnede seksualkategoriseringer, vores kultur ulykkeligvis er indfanget og indspundet $i$.

\section{HERMAN BANG}

I forbindelsen med Herman Bangs forfatterskab er situationen en anden. Da Herman Bang (1857-1912) både for sin samtid og for eftertiden nærmest er blevet et syno- nym for moderne homoseksualitet, skal historiceringen snarere fokusere på Bangs rolle som pioner for en radikalt moderne homoseksualitet, og hele hans forfatterskab kan genlæses som en lang række forhandlinger med heteronormativiteten. Bangs værk og biografi er et enestående knudepunkt for forbindelseslinjer mellem urbanitet, dekadence, modernitet, kapitalisme, kunst og homoseksualitet. Hans litterære værk og offentlige persona befinder sig netop i spændingsfeltet mellem mange af de af Sedgwick foreslåede homo-heteroseksualitetsmarkerede binarismer: gammel/ny, dansk/udenlandsk, hemmeligholdelse/afsløring, helhed/dekadence, kunst/kitsch, naturlighed/ kunstighed, land/by, rask/ syg, xgthed/ sentimentalitet. Således kan Herman Bang betragtes som en prisme, der afspejler centrale historiske vendepunkter i den vestlige verdens omgang med homosocialt begær.

Det ville være synd at sige, at homoseksualiteten har været fraværende i sekundærlitteraturen til Herman Bang, men dens status som fortolkningskategori er problematisk. Samtlige Bang-studier har været foretaget af heteroseksuelle litterater, der alle har det til fælles, at de ved, hvad Bangs homoseksualitet var, og hvad den har betydet for hans forfatterskab. Med hyppigt psykoanalytisk terminologi har de kunnet dechifrere værket ud fra en uproblematiseret "mer-viden", som de alene qua deres heteroseksualitet har anset sig i besiddelse af jf. den norske litterat Pål Bjørbys xtsende forskningoversigt, "The Prison House of Sexuality", som viser, hvordan generationer af Bang-forskere i snart hundrede år har "behandlet" forfatterskabet.

En gen- og nylæsning af Bangs forfatterskab skal naturligvis undersøge de mulige forklædninger og de homoseksuelle koder i teksterne, således som den norske - alt for tidligt afdøde - litterat, Øystein Ziener, har gjort det i sin fintmærkende nærlæsning af Stuk fra 1887 i Homoseksualitet? Homotekstualitet? (2001). Men det er et spørgsmål om hans overbegreb "homotekstualitet", 
en særligt "homoseksuel" skrivestrategi, ikke er en problematisk mystifikation. At homoseksualitet kan have indflydelse på en homoseksuel forfatters værk, er vel ingen urimelig påstand, men undersøgelser må tage udgangspunkt i det enkelte værk, og hver eneste gang stille spørgsmålet om, hvilken homoseksualitet og hvilken tekstualitet, på samme måde som heteroseksualitet jo også er en abstraktion, som må undersøges konkret i hvert enkelt tilfælde.

Herman Bangs berømte og skandaløse debutroman Haabløse Slegter fra 1880, som indkasserede forfatteren en dom for usædelighed, må selvfølgelig nylæses i en queer eller skæv - optik, som homoseksuel "misdannelsesroman". Den er dansk litteraturs første udfoldede skildring af en seksuelt besynderlig skæbne, en besynderlighed, som også kan - og må - læses som en homoseksuel allegori. Haabløse Slegter kan læses som et årsagskatalog for homoseksualitetens opståen, idet den oplister en lang række faktorer som bestemmende for den ulykkelige og plagede forfatterspire William Høgs besynderlighed: tidens dekadence, slægtens degeneration, faderens sindssyge, moderens kærlighedsfrustration, hendes problematiske graviditet, den vanskelige fødsel, drengens fysiske særheder, hans unaturlige opdragelse, den for stærke moderpåvirkning, den farlige moderidentifikation, moderens tidlige død, drengens fordærvende ungdomslæsning og endeligt to særdeles farlige og destruktive forhold til to meget mærkelige, ældre "kvinder", der glubsk kaster sig over den følsomme og påvirkelige yngling.

Resultatet er goldhed og en uhyggelig forfaldsproces, hvor William som 22-årig fremstår som olding - besynderligt opbrugt. Selvmordet lurer lige om hjørnet, i hvert fald $\mathrm{i}$ anden udgave af romanen fra 1884, som slap gennem censuren. Her er en epilog om Williams senere skxbne udeladt, og det antydes stærkere, at hovedpersonen som uselvisk gestus tager sit liv. At lade den besynderlige person dø ung og for egen hånd var en måde at gøre romanen mere "moralsk" på. For en god homoseksuel er en død homoseksuel. ${ }^{2}$

Også Bangs berømte og populære "kvinderomaner", Ved Vejen, Tine, Det hvide Hus og Ludvigsbakke kan som eksperiment læses som - også - homoseksuelle allegorier, hvor de $x$ delt kærlighedslidende heltinder, der typisk dør pga. uxgteskabelige lidenskaber, måske kan læses som romantiserede versioner af ulykkelige homoseksuelle mænd, der også lider under samfundets normer. Også de er uskyldige ofre i hænderne på en ubarmhjertig natur, der har nedlagt en drift i dem, som de må lyde, den skxbne, som Herman Bang så dramatisk iscenesætter i sit posthumt udgivne essay, Gedanken zum Sexualitätsproblem (1922); et essay, som måske kan læses som også en poetik over hele hans forfatterskab. ${ }^{3}$ Herman Bang er et litteraturhistorisk eksempel på, hvordan homoseksualiteten er blevet alt andet end fortiet, men derimod fàet en helt overgribende hermeneutisk status, som tilsyneladende kan forklare såvel værk som biografi, og hvor der er frit fortolkningsslag for hvem som helst, bare man er heteroseksuel.

\section{JOHANNES V. JENSEN}

Hvis Herman Bang er prototypen på den homoseksuelle i dansk litteratur, er Johannes V. Jensen (1873-1950) prototypen på den moderne homofob. Litteraturhistorien har da også taget behørigt afstand fra især hans herostratisk berømte udfald mod Herman Bang i Politiken-kronikken, "Samfundet og Sædelighedsforbryderen" fra 1906; et bemærkelsesværdigt paranoidt angreb mod homoseksuelle, som også er præget af angsten for selv at blive anset for at være homoseksuel, en mistanke, der besværges med vold: "og for Resten saa lad hvem der vil komme frem og prove mig personlig, jeg er til enbver Tid rede med Kap eller de bare Never" (Politiken 30.11.1906).

Dette homofobe beredskab, som Jensen "til enhver Tid" er prxget af, påvirker naturligvis også hans forfatterskab. Men skønt 
mandsmandsbegær spiller en afgørende rolle i flere af værkerne, har den righoldige sekundærlitteratur ikke beskæftiget sig med det. Kongens Fald fra 1900-1 blev precis hundrede år efter udråbt til intet mindre end det tyvende århundredes væsentligste danske roman. Ikke desto mindre er receptionen af teksten præget af blinde pletter på størrelse med mindre kontinenter.

Et helt centralt smertepunkt i Jensens formidable stykke danmarkshistorie er hovedpersonen Mikkel Thøgersens smertefulde forvaltninger af sin kærlighed til en række mænd. Den forste er Otte Iversen, som Mikkel må lære at hade for at overleve:

"Men han var ung, endnu kunde hans Lidenskaber ikke bestaa i sig selv, de krævede et Objekt. Og saa vendte al hans Smærte sig da til Had, Had mod ham Otte Iversen. Den Tanke frelste ham, at lægge Otte Iversen øde" (Jensen 1900-1, 52).

Senere gælder hans dræbende kærlighed Ottes (uægte) søn, Aksel, som han bliver ven med, men hvis kærlighed, han ikke kan rumme og derfor gådefuldt må slå ihjel:

"Han var en Afmagt nær, ligesom et Menneske, der ikke kan faa sagt, at han elsker, og vil sige det” (Jensen 1900-1, 150).

Romanen synes struktureret af en besynderlig dræbende vitalisme, hvor mænds overlevelse er betinget af deres evne til at holde begæret til andre mænd i skak. Romanen slutter med en form for homosocial happy end, hvor Mikkel mod slutningen af sit liv lever i næsten xgteskabelig harmoni med den beundrede konge, Christian II, indespærret på Sønderborg Slot. Men et uhyggeligt intermezzo med en Herman Bang-lignende troldmand, Zacharias, og dennes drengemonstrum, Carolus, virker som en advarsel mod relationens mulige homoseksuelle konnotationer. ${ }^{4}$ Efter Mikkels besøg hos troldmanden brændes $\mathrm{Za}$ charias og Carolus på bålet, men troldman- den dør med Mikkels navn på sine læber. Dagen før har den lumre personage dog ladet den skrækslagne Mikkel føle på drengens stærkt falliske "hoved":

"Mikkel følte modvilligt paa det bløde Hoved, der allerede var meget varmt og bankede uroligt.

Ja vi kan godt gaa, sagde Zacharias, han er langt inde i Opgaven. Men det vil vare over en Time, inden Hovedet er fyldt og spændt. Han ser rigtig godt ud, naar han er fuldt opsvulmet og sidder som et Stilk paa sit eget Modne Hoved" (Jensen 1900-1, 222).

Johannes V. Jensens forfatterskab er et af dansk litteraturs interessante kilder til, hvordan og hvornår homo-heteroseksualitetsdefineringskrisen for alvor blev et problem i det moderne Danmark.

\section{KaREN BLIXEN}

Karen Blixens forfatterskab er nok dansk litteraturs største og mest spektakulære opvisning af perversionsgallerier. Det har krævet meget besværgelse og megen bortforklaring og bortmaning ikke at se det oplagte: at ikke mindst den vægtige debutbog Syv fantastiske Fortallinger fra 1935 er gennemsyret af kønsballade og seksuel uortodoksi. Berlingske Tidendes forfærdede og bornerte anmelder, Frederik Schyberg, var ikke sen til at påpege bogens grundlæggende perverse natur i sin berømte anmeldelse fra 1935. Her spørger han, efter at have anklaget bogen for snobberi og pastiche:

\section{"Men hvad med Perversiteten?}

Ordet er grimt, men der findes intet andet, naar man skal betegne den Kendsgerning, at der $i$ de syv Fortellinger ingen normale Mennesker findes. Bogens elementære Inddeling af de to Køn bestaar i, at alle dens unge Mænd er effeminerede, ifører sig deres Søstres Tøj og uforligneligt spiller Dameroller i Dilletantkomedier til Kenderes Henrykkelse og alle dens unge Kvinder er mandhaftige, gaar paa 
Vildsvinejagt, klæder sig ud som Mænd og efter Tur sammenlignes med Bataillonschefer(?), Matrosdrenge, der spuler Dæk, eller Grenaderer.

Det erotiske Liv, der udfolder sig i Fortællingerne, er derfor af højst sælsom Art. Mænd elsker deres Søstre, Tanter deres Niecer, enkelte af Personerne er forelsket i sig selv, og unge Kvinder kan ingen Børn faa, eller vil ingen have, en fransk Grevinde slynger sin Elsker i Ansigtet, at han ikke er forelsket i hende, men i hendes Mand - og han ved intet at svare hende, fordi han "indser", at hun har Ret. Erotikken afspores yderligere og giver sig "gotiske" Udslag. Augustus von Schimmelmann bliver skilt fra sin Hustru, fordi han er forelsket i hendes Diamanter! Senere udløser en italiensk Lugteflaske hans Komplekser.

Morten de Coninck er forelsket i sit Skib "Fortuna", Baron Brackel og Grev Boris nærer Følelser henholdsvis for en Hjerneskal og et helt Skelet. Det er ikke noget Anmelderen finder paa, der er blot Indholdet af de fantastiske Fortællinger, berøvet alle Slør” (Berlingske Tidende 25.9.1935).

Schybergs afsløring er et godt eksempel på, at det ofte er moralsk anfægtede læsere, der har det skarpeste blik for seksuelle og kønslige overskridelser og udfordringer. Parafrasen foregriber den senere kønsforsknings koblinger mellem "ballade" på det kønslige niveau og dets følger på det seksuelle, mest prægnant formuleret af den postfeministiske amerikanske kønsfilosof Judith Butlers nu klassiske bog Gender Trouble (1990), der sætter kønnet "på komedie" ved, på "mærkværdiggørende" vis, at beskrive det som først og fremmest et eksistensscript, som kun lader sig opretholde gennem konstante og ritualiserede citeringer af "maskulinitet" og "femininitet", citeringer, der har "den heteroseksuelle matrice" som central disciplineringsstruktur. Uden heteroseksualitet, intet køn, lyder en af Butlers provokationer, en provokation som Karen Blixen på endnu mere subtil og fantasifuld vis må siges at have foregrebet.

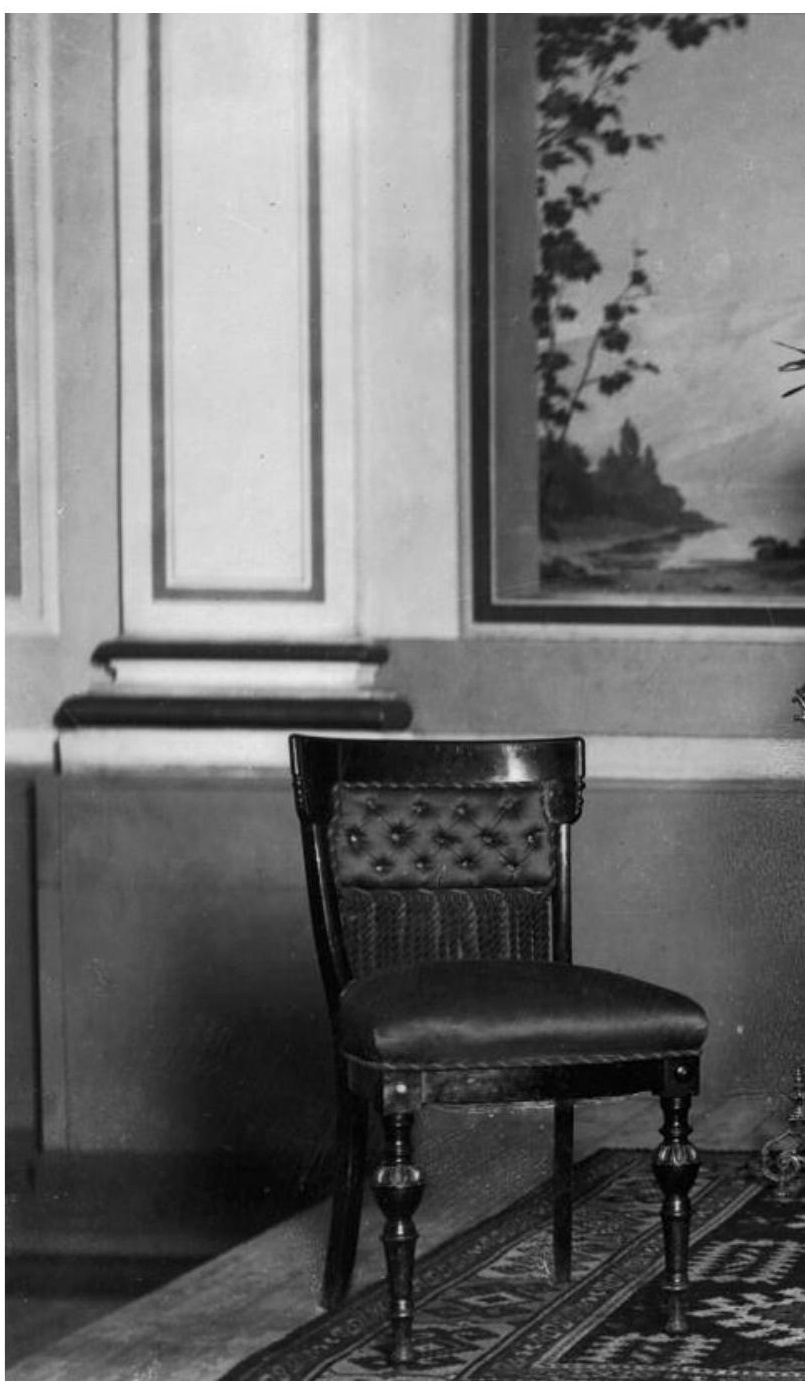

Schybergs anmeldelse, som flere generationer af Blixen-forskere næsten rituelt har måttet fornægte og besværge som indledning til deres forskning, giver et præcist billede af oplagte fænomener hos især den tidlige Karen Blixen (1885-1962), hvor kønnet er en changerende og ustabil kategori, hvad der naturligvis også vanskeliggør enhver tale om homo- og heteroseksualitet. For når personerne ikke er sikre på hverken deres eget eller partnerens køn, er det praktisk talt umuligt at bestemme hvad, der er det modsatte. Det blixen'ske univers rummer et væld af destabiliseringer og dekonstruktioner af såvel køn som heteroseksuali- 


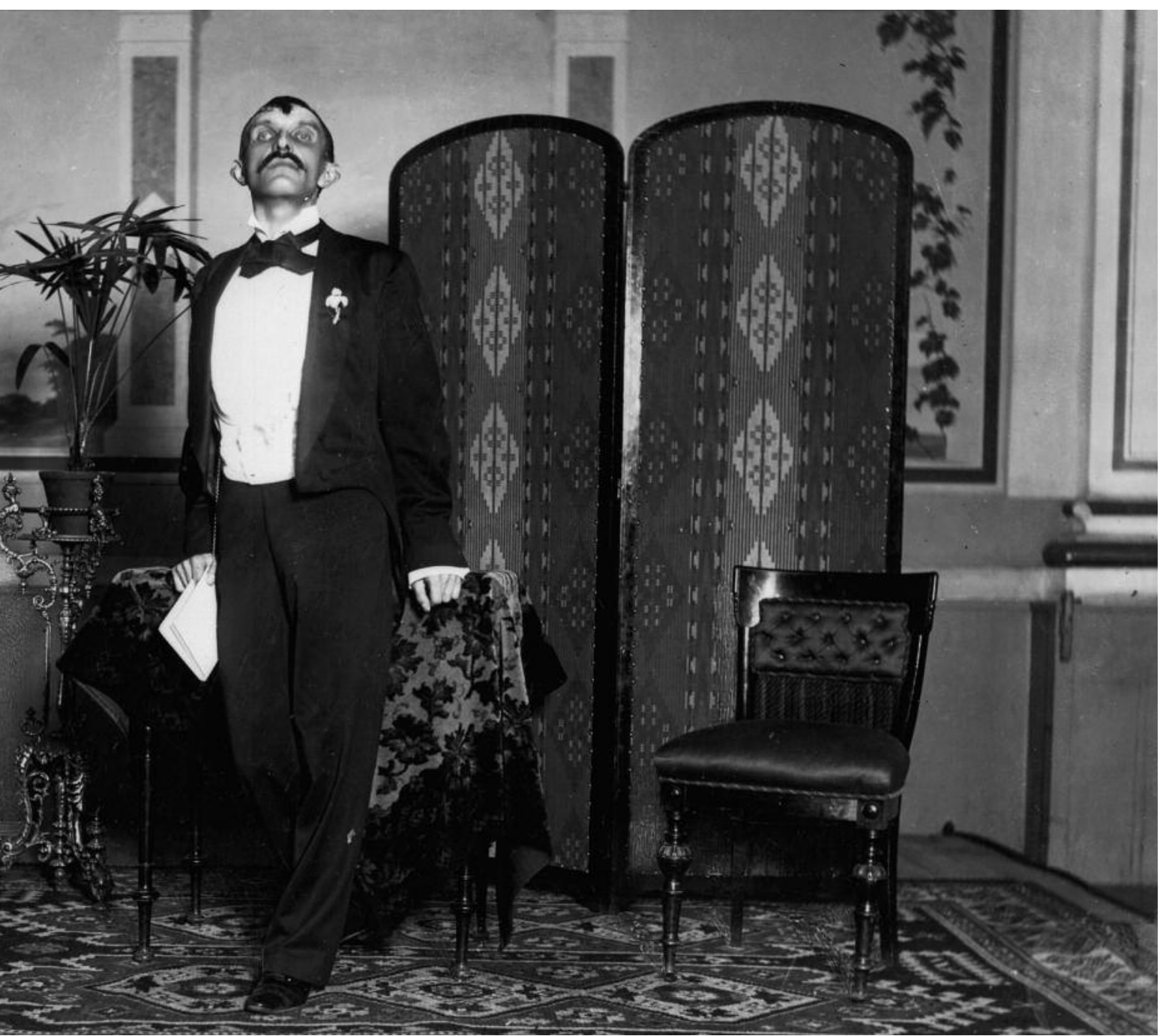

tet og opviser en lang række farverige og spektakulære tableauer af uortodokst begær. Bl.a. rummer det en besynderlig grundpåstand om, at mænd (i det omfang kønnet kan sandsynliggøres naturligvis!) egentlig foretrækker mænd, men for en tid kaster sig ud i forbindelser med kvinder (hvis de da er det!), forbindelser der typisk ender ulykkeligt og ofte sågar med dødelig udgang. Eller også bliver det kedeligt og forlades. Den heteroseksuelle happy end er typisk et antiklimaks hos Blixen. Groft sagt kan man sige, at hos Karen Blixen er mand og kvinde ikke kun gift med hinanden, men også gift for hinanden.
Således anvendes to tilsyneladende modsatrettede strategier for at "mærkværdigg $\varnothing$ re" heteroseksualiteten: dæmonisering og banalisering: heteroseksualiteten er typisk dræbende eller dræbende kedsommelig, mens den narrative frugtbarhed henviser til det seksuelt ufrugtbare. ${ }^{5}$ Blixens forfatterskab opviser således sin egen perverse poetik, som det har krævet mange heteronormative besværgelser og biografiske mystifikationer at forplumre.

KLaus RifBJerG

Gymnasieklassikeren Den kroniske uskyld 
(1958) af Klaus Rifbjerg (f. 1931) er et skræmmende eksempel på, hvordan homofobi og misogyni formidles ukritisk til generationer af unge danskere. Romanen er et af det danske uddannelsessystems mest anvendte værker. Men sekundærlitteraturen har uden undtagelse fornægtet eller banaliseret homoseksualiteten og fortiet misogynien i det komplekse værk.

Den kroniske uskyld er en jeg-fortxlling af den unge Janus Tolne. Hovedparten af teksten fokuserer på hans umulige og uformulerbare kærlighed til vennen, Tore, som "man" ifølge Janus bare ikke kan lade være med at elske. Romanen er et tilbageblik på en række dramatiske begivenheder, som Janus søger at komme til rette med. Den tager udgangspunkt i det første møde med Tore i barndommen og følger venskabet i teenageårene, hvor Tore forelsker sig i Helle med Janus som tredje hjul i forholdet. Forholdet ødelægges af Helles dæmoniske moder, der ved en skæbnesvanger studenterfest, som også skulle have været Helle og Tores forlovelsesgilde, forfører Tore; samme nat begår Helle selvmord. Teksten slutter på et sindssygehospital, hvor Tore er indlagt med Janus som trofast besøgende.

Tekstens fortælleforhold og manglende kohærens peger tilbage på Janus uafklarethed, blinde punkter og smertelige fortrængninger. Den urealistisk skildrede Fru Junkersen-figur kan læses som en personifikation af den jalousi, Janus massivt fortrænger, og som således kun kan komme til syne som en grotesk forvrænget og misogyn fantasi. Misogynien præger også hele Janus forhold til kvinderne, som han nedlægger på stribe, men behandler med sadistisk foragt. Samme dag som studenterfesten har han f.eks. voldtaget og er nær ved at dræbe sin kæreste, et faktum som den omfattende sekundærlitteratur fuldstændig har ignoreret. Janus misogyni synes at have smittet af på samt- lige mandlige læsere. Man kan kun håbe, at dette ikke reproduceres $\mathrm{i}$ de mange undervisningssammenhænge, romanen indgår i.

\section{Kirsten Thorup}

Det er ikke kun afdøde forfattere som Karen Blixen, hvis queer potentialer skal nyopdages. En modernistisk realist som Kirsten Thorup (f. 1942) har bl.a. i sin roman Baby (1973) skabt en fantastisk fortælling i et univers, hvor heteronormativiteten som ordningsstruktur på forunderlig vis er sat helt ud af kraft. I romanens verden, der hovedsageligt foregår i københavnske slumkvarterer, forstår samtlige personer sig selv og hinanden på tværs af køn og seksualiteter. Alle vægrer sig ved at fastholdes i et køn. Pigerne Nova og Susi er bogstavelig talt "blodsøstre"; de har dræbt en mand, men deres kærlighed på liv og død undgår totalt lesbiske kategoriseringer. Ivan og Rick er - også i genitalseksuel henseende elskende, men deres "homoseksualitet" italesættes, problematiseres eller diagnosticeres aldrig. Marc og Cadett er et "heteroseksuelt" xgtepar, men hun er den aktivt begærende med det praktiske og rationelle overblik, mens han er det forfængelige, ufornuftige sexobjekt, der ikke kan håndtere en selvstændig eksistens.

Romanens rædselsscenario er det enestående traditionelt heteroseksuelle forhold mellem Leni og bolig- og lånehajen, Eddi, der fremstilles som en destruktiv og sadomasochistisk konstruktion, en hyperbol patriarkalsk parodi, der i modsætning til de andre storbyforhold finder sted i et velhavende forstadsmiljø. Romanens skrøbelige utopi er heroverfor et forhold, der bygger på en grundlæggende "kønsballade". Den slutter med den spirende romance mellem den drengede Leni, falleret pornobogsforfatter og forslået eks-kone, og transvestitten Jolly Daisy, en næsten magisk figur, der trods sin åbenlyse narcissisme fremstår som en visionær kaospilot i tekstens flydende kønsunivers. Jolly Daisy legemliggør forestillingen om kønnet som overflade, og hun (han) arbejder bevidst og professionelt med kønnet som maskerade. 


\section{AFSLUTNING}

Disse stikprøver, som naturligvis kræver langt mere argumentation, har forhåbentligt kunnet antyde, at den danske litteraturhistorie ikke bare skal omdefineres, men nyskrives. Der er ikke blot tale om at supplere de gxngse litteraturhistorier med glemt eller fortrængt homoseksualitet, at korrigere homofobiske udsagn, eller gøre studierne politisk korrekte ved at ajourføre dem til den køns- og seksualitetspolitiske status quo i Danmark i begyndelsen af det enogtyvende århundrede. Det er først og fremmest radikalt nye spørgsmål, der skal stilles fra radikalt forskellige steder.

I modsætning til kvindelitteraturhistorierne handler en mærkelig ny litteraturhistorie ikke i første omgang om at fremdrage glemte forfatterskaber, der er blevet undertrykt pga. forfatternes $\mathrm{k} ø$ og seksualitet. Det handler først og fremmest om at genlæse (og omdefinere) hele den litterære kanon for at se, hvordan der i de enkelte tilfælde "forhandles" med den kulturelle homo/heteroseksualitets-defineringskrise. Det er min pointe, at ingen moderne forfatterskaber, hverken med homo- eller heteroseksuelle ophavsmænd og temaer, er uberørte af denne krise. Således er ingen værker på forhånd fredet fra den mærkelige litteraturhistorieskrivning, og det er måske især i dem, som det synes mest utilladeligt at beskæftige sig med, at der er mest at hente.

\section{NOTER}

1. Tak til Kvinder, Køn \& Forsknings anonyme referee for grundig og konstruktiv kritik.

2. Jf. min analyse af homoseksuelle selvbiografier, "Dødebøger", i Livet som indsats (red. Sven Halse), Syddansk Universitetsforlag, Odense, 2003. 3. Dette har jeg udfoldet i Herman Bang. Morkvardige lasninger; Odense: Syddansk Universitetsforlag, 2003.

4. Jf. Maja Bissenbakker Frederiksens læsning af romanen i Synsvinkler 28/2003.

5. Dette har jeg udfoldet i Det umenneskelige. Analyser af seksualitet, kon og identitet hos Karen Blixen, Odense Universitetsforlag, Odense, 2001.

\section{LITTERATUR}

- Bang, Herman (1880): Haabløse Slagter. J.H.

Schubothes Boghandel, København.

- Bang, Herman (1922): Gedanken zum Sexualitätsproblem. Marcus \& Weber Verlag, Bonn.

. Bjørby, Paal (1986): “The Prison House of

Sexuality", in: Scandinavian Studies 58/1986.

- Blixen, Karen (1935): Syp fantastiske Fortallinger.

Gyldendal, København.

- Butler, Judith (1990): Gender Trouble. Routledge, New York \& London.

- Detering, Heinrich (1994): Das offene Geheimnis.

Wallenstein Verlag, Göttingen.

- Foucault, Michel (1976): La volonté de savoir.

Gallimard, Paris.

- Jensen, Johannes V. (1900-1): Kongens Fald.

Gyldendals Bogklub, 1969, København.

- Rifbjerg, Klaus (1958): Den kroniske uskyld. Gyldendal, København.

- von Rosen, Wilhelm (1994): Månens kulør. Rhodos, København.

- Sedgwick, Eve Kosofsky (1990): The Epistemology of the Closet. Penguin Books, 1994, London.

. Thorup, Kirsten (1973): Baby. Gyldendal.

København.

-Wullschlager, Jackie (2000): Hans Christian Andersen. Chicago University Press, Chicago.

- Ziener, Øystein S. og Jørgen Lorentzen (2001): Homoseksualitet? Homotekstualitet? Unipub forlag, Oslo.

\section{SUMMARY}

Taking queer critic Eve Kosofsky Sedgwick as a point of departure, this article discusses the need for a radical rewriting of the history of Danish literature. This queering of the Danish canon must consider the chronic crisis in modern bomo-heterosexual definitions, and how every work, every writer and every literary period negotiate it. A number of brief examples of literary queerings of canonical Danish literature are given with works by Hans Christian Andersen, Herman Bang, Johannes V. Jensen, Karen Blixen (Isak Dinesen), Klaus Rifbjerg and Kirsten Thorup.

Dag Heede, ph.d, lektor

Institut for Litteratur, Kultur og Medier

Syddansk Universitet 